\title{
Web-based and traditional public participation in comprehensive planning: a comparative study
}

\author{
Eliahu Stern, Ori Gudes, Tal Svoray \\ Department of Geography and Environmental Development, Ben-Gurion University of Negev, \\ Beer Sheva 84105, Israel; e-mail: elistern@bgu.ac.il, gudeso@gmail.com, tsvoray@bgu.ac.il \\ Received 5 October 2007; in revised form 8 September 2008; published online 2 October 2009
}

\begin{abstract}
The present paper examines whether the potential advantages of the expanding practice of web-based public participation only complement the benefits of the traditional techniques, or whether they are empowering enough to replace them. The question is examined in a real-world case of neighborhood revitalization, in which both techniques were practiced simultaneously. Comparisons are made at four major planning junctions, in order to study the contributions of each technique to the qualities of involvement, trust, and empowerment. The results show that web-based participants not only differ from the participation of traditional practices, but they also differ from each other on the basis of their type of web participation. The results indicate that web-based participation is an effective complementary means of public participation, but it cannot replace the traditional unmediated techniques.
\end{abstract}

\section{Introduction}

The growing interest in web-based public participation (WPP) has encouraged a rapid expansion of research, especially in countries practicing public participation in decision making and planning (eg Carver, 2001). Studies have investigated the potential advantages of the WPP versions (eg Kingston et al, 2001; Schroeder et al, 2001), as well as their relevance to various types of planning and management systems (eg Han and Peng, 2003).

It seems that the growing interest in WPP techniques forsakes the traditional techniques of public participation (TPP), which are mainly based on various types of face-to-face contact. Although a few studies have tried to compare the use and benefits of WPP with the use and benefits of TPP, they have mainly involved physical planning, in the form of reactions either to actual building layout and design (eg Kingston et al, 2001), or to land-use schemes (eg Hamilton et al, 2001; Talmor, 2006). The empirical comparative studies only and specifically measure the benefits and the use of public participation geographic information systems [PPGIS - eg see the current reviews of Sieber (2006), and Dunn (2007)], or offer specific criteria for evaluating PPGIS (eg Brandt, 2002). The comparative usage and benefits of TPP and WPP practices in actual comprehensive planning remains underexamined in the evaluation literature. Can the potential advantages of WPP only complement the benefits of TPP, or are they empowering enough to replace them? This basic question led us to examine the quantitative and contextual contributions of WPP, in comparison to the contributions of TPP, in an actual comprehensive planning process of neighborhood revitalization in Tel-Aviv, Israel. Within this framework, we also looked at two specific subquestions:

(1) Do the web-based participants differ from the participants in the traditional process?

(2) In what ways does WPP contribute to the empowerment of the public?

We looked at these questions in a real-world case, in which both WPP and TPP were practiced simultaneously. 


\section{Benefits of public participation and research hypotheses}

It is widely agreed that increased public participation in planning produces many benefits (eg Halvorsen, 2003; Lane, 2005; Stern and Amir, 2006). Dissent in this case is rare: "it is difficult to envision anything but positive outcomes from citizens joining the decision making process" (Irvin and Stansbury, 2004, page 55). Planning scholars have argued that citizen participation can generate trust, credibility, and commitment, regarding the implementation of planning and other policies, and can build social capital (Brody et al, 2003; Burby, 2003). Public participation can also create a sense of ownership over a plan and can reduce conflict over the long term, because those involved feel responsible for its policies (Wondolleck and Yaffee, 2000). Other benefits are empowerment (Sarno, 2005) and the introduction of valuable knowledge and innovative ideas that can increase the quality of the adopted plans (Forester, 1998). There are certainly additional benefits mentioned in the literature, but the evaluation of the effectiveness and the benefits of public participation can only be understood in terms of the decision-making context in which it is embedded (Lane, 2005) and the scale of planning (Stern, 2002). Therefore, when comparing the benefits derived from WPP with those from TPP, we should consider the characteristics of both approaches, within a given planning scale and context, in determining: (a) the beneficiaries, and (b) the benefits.

Public participation contributes mainly to four beneficiaries: the public, the planners, the local municipality, and the plan itself (Stern and Amir, 2006). Assuming that, apart from the-usually technical-limitations of WPP, the basic benefits of TPP can be also achieved by WPP, the main limitations of WPP include potentially limited access to the Internet, which may affect the number and socioeconomics of the participants (Craig et al, 2002), their knowledge in operating the computer and the web, and the friendly interface needed to encourage them to use this technology. On the other hand, WPP has some advantages over TPP. In appropriate cases, WPP enables the public to participate in the process, anywhere and anytime. In these cases, it also provides higher accessibility to a wider public, along with updated and visual information (Kingston et al, 2001). It enables free individual expression, without public exposure or social pressure (Carver, 2001). There is evidence that these qualities increase the number of participants and the public involvement, and, consequently, contribute to community empowerment and trust both in the planning process and in the local authorities (Sarjakoski, 1998; Trevor, 1998). These qualities were combined by Jeffries (1996) into three dimensions - involvement, trust, and empowerment - in order to examine the role and the benefits of public participation in planning. As WPP is expected to strengthen these qualities over TPP (eg Peng, 2001), we used the Jeffries model (figure 1) as a conceptual framework to examine the following, consequent, hypotheses.

\section{(a) Involvement}

Involvement in general often refers to an individual's participation in a given task and is measured as a set of behaviors or activities that such an individual performs (Barki and Hartwick, 1989). However, some studies suggest a separation between the constructs of participation as a set of behaviors and performed activities, and involvement, which is seen as a subjective psychological state reflecting the importance and personal relevance of a given framework to the participant (Barki and Hartwick, 1994). It is claimed that such a distinction is more consistent with conceptualizations of involvement found in various other disciplines. In our case, where WPP offers a variety of new qualities to and opportunities for public participation, this theoretical distinction seems appropriate. Relating to Jeffries's (1996) low - high scale of public involvement, 


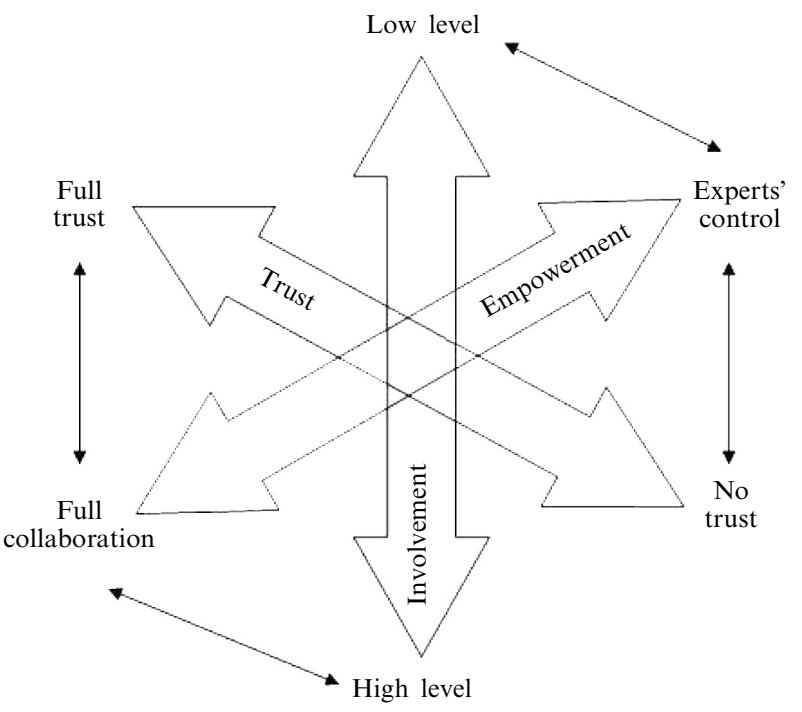

Figure 1. The Jeffries model.

we accordingly hypothesize that the use of WPP will not only enable more citizens to be engaged in the planning process, but it will also increase their involvement and participation, as defined above.

\section{(b) Trust}

The vast literature on public participation has long indicated that effective public participation implies more than finding the right tools for increasing public involvement. Effective public participation should work for all parties and stimulate interest and investment both in administrators and in citizens (King et al, 1998). This, in turn, requires that trust should be developed throughout the participation process (eg Webler et al, 2004). It is argued that the quality of public participation can positively affect citizen trust (Halvorsen, 2003). However, achieving this goal requires good communication and commitment throughout the participatory process (Beierle and Kosinsky, 2000). It is built up gradually, usually from a state where trust does not exist, to full trust at the end of the participation process. In municipally initiated planning, as in the present case in Tel-Aviv, citizens of deteriorated neighborhoods often suspect the authorities' intentions. Therefore, trust must first be built between the citizens and the authorities. We may thus hypothesize that trust will be gradually increased, as and if the citizens become convinced that they will be the first and main beneficiaries of the plan. We may assume further that trust and involvement are interrelated. Involvement and participation, as defined above, cannot be developed without trust and vice versa. Therefore, the ability of web-based participation to provide good communication and continuously updated information, as well as being a means for better democratic decision making, is also hypothesized to increase public trust.

\section{(c) Empowerment}

As recently reviewed by Elwood (2001), a wide array of definitions of empowerment have been developed and employed in social science research. In the planning arena a large number of studies conceive empowerment as constituting capacity building, generally framed as an expansion in the ability of citizens or communities to take action on their own behalf. It includes the acquisition of new skills that help individuals and communities actively to exert control over their circumstances (eg Rappaport, 1984; 
Zimmerman, 1990; Zimmerman and Rappaport, 1988). It thus expresses the level of effect and control that the public is given and achieves in the planning process.

According to Jeffries's (1996) framework, full control by experts would express no level of empowerment, whereas full public collaboration, throughout the planning and its implementation stages, would entail and reflect the highest level of empowerment. WPP enables more people to express their opinion, to proposed solutions, alternatives, further projects, and even to vote, regardless of their location or any other subjective limitation. The detailed, updated, accessible, and always available information also increases personal confidence, which consequently encourages involvement and active participation. Therefore, we hypothesize that WPP will increase public empowerment, especially in a multitask comprehensive planning that provides the public with a range of intervention opportunities.

\section{Methodology}

\section{General procedure}

The study compares quantitative and contextual contributions of WPP and TPP at four major junctions (A-D in figure 2) throughout the year-long planning process of the Shapira neighborhood in Tel-Aviv. The neighborhood is a multicultural residential quarter in the southern part of the city. It is part of four socially and economically deteriorating neighborhoods undergoing a participatory-based process of urban revival. As shown in figure 2, WPP provided the public with access to the same information presented to those participating in the TPP through public meetings. At each junction, participants of both techniques could discuss, debate, evaluate, and/or vote, according to the stage-relevant subject. While TPP participants - in face-to-face meetings and focal groups-could interface with the planners and municipal officials, and could view key issues and problems, the defined goals and objectives, the formulated and evaluated alternatives, the projects, and other solutions, WPP participants could do the same through continuous electronic chatting.

A questionnaire was distributed to the TPP participants at the end of each meeting. WPP participants were similarly asked to fill in an identical, online, questionnaire, although their feedback was spread along an extended period. Accordingly, the data in total include eight groups of questionnaires, two after each planning stage. Comparisons were then made between the techniques and the planning stages with data-constructed indicators, thereby reflecting potential, subjective contributions to the dimensions of the conceptual framework. Objective data were also used to assess some of the hypotheses as explained hereafter.

Several means were used simultaneously to recruit participants. Local youth volunteers distributed 1200 brochures among the residential mailboxes and posted 100 posters on public billboards. The local newsletter and the local community center cooperated in disseminating information about the participation process and the website, and a hyperlink to the Shapira website as added to the Tel-Aviv municipal portal.

\section{Indicators}

Data-based indicators for each of the hypothesized dimensions were partially selected from studies related to the Jeffries model (published in Churchman and Sadan, 2003) and partially from other relevant literature sources. Objective indicators were partially extracted from the monitoring data of the accompanied website.

Involvement was measured to reflect both components of participation and involvement, as theoretically defined above. Involvement, presenting the personal relevance of a given participation framework, was measured by a subjective, $1-5$ scale 


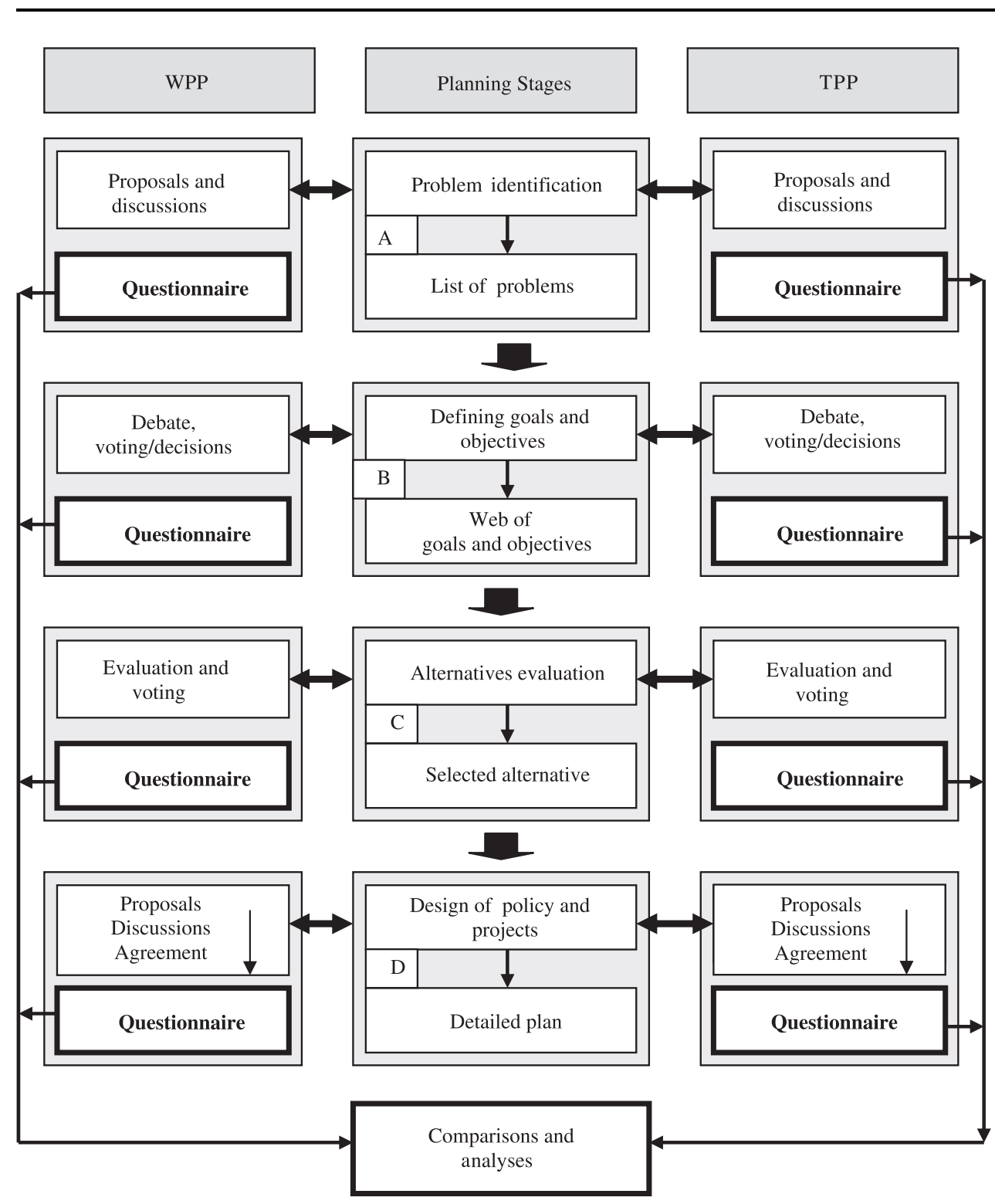

Figure 2. The overall research structure and the planning stages of the Shapira neighborhood in Tel Aviv. TPP denotes traditional public participation; WPP denotes web public participation.

of self-evaluations of involvement. Participation, which presents a set of behaviors and performed activities, was measured, objectively, by the number of questionnaires filled out by each participant throughout the two most effective stages of the planning process: (C) the design and evaluation of alternatives; and (D) the formation of policies and means for their implementation. In these stages participants had the highest opportunity actually to participate and affect the planning through questionnaire-type opinion expression and voting.

Trust is often measured in social science research in both direct and indirect ways (eg Glaeser et al, 2000). Similarly, it has been evaluated here by both direct-subjective and indirect-objective indicators. The subjective indicator was based on the abovementioned assumption that participants must be convinced that the main beneficiary 
will be the public and not other stakeholders. Therefore, the higher the 'public' was evaluated by the participants as the main beneficiary of the plan, the higher the level of the participants' trust in the plan was adjudged to be. Accordingly, the subjective measure is the participants' evaluated distribution of the following potential beneficiaries: 'the public', 'the planners', 'the municipality', and 'others'. The evaluation was conducted among both TPP and WPP participants. Since trust is expected, by nature, to develop gradually throughout the participation process, the evaluated distribution of beneficiaries was examined at each stage of the planning.

The objective indicator relates to the hypothesis of interrelationship between participation and trust. It thus stems from a quantitative, inductive, analysis of 'first-time' and repeated entries to the participatory website. A 'first-time' entry was defined as someone who entered the website for the first time. At his or her first entry, the website script used a cookie to extract the user's Internet protocol address, thus enabling the system to monitor repeated entries by the same user. Temporal growth of first-time entries generally reflects a growing interest in the planning endeavor, while the growth of repeated entries by the same users reflects steady participation and continued involvement, which, in turn, indicates a growing trust.

Empowerment is measured only with stage-related, subjectively evaluated, indicators. The vast literature on the subject offers a variety of ways to estimate empowerment. A wide typology and a consequent ladder of empowerment was proposed by Rocha (1997), so that planners and others might gain in a clearer understanding of empowerment and its varied potential. However, we decided to adopt, as a base, the working definition of empowerment offered by Chamberline (1997). It was designed after long discussions and is expressed by fifteen qualities, six of which are the most relevant to our planning case study (table 1): (a) access to information; (b) satisfaction with the process of public participation; (c) affecting change; (d) feelings of making a difference; (e) becoming partners; and (f) self-commitment. This order, from 'access to information' to 'self-commitment', as presented in table 1, reflects the development continuum of empowerment throughout the planning period. Therefore, 'becoming partners' and self-commitment' show up only in its last two stages. Table 1 also presents the subjective 1-5 scale evaluations that operationally reflect each of these qualities.

Table 1. Empowerment qualities and their indicators.

\begin{tabular}{|c|c|c|}
\hline Empowerment quality & $\begin{array}{l}\text { Quality indictor (scalewise subjective } \\
\text { evaluations) }\end{array}$ & $\begin{array}{l}\text { Planning } \\
\text { stages }\end{array}$ \\
\hline Access to information & respective evaluations & $\mathrm{A}-\mathrm{D}$ \\
\hline Affecting change & $\begin{array}{l}\text { ability to affect formulation of goals and } \\
\text { objectives } \\
\text { ability to affect evaluation and selection of } \\
\text { alternatives } \\
\text { ability to affect resolution of conflict }\end{array}$ & $\begin{array}{l}\mathrm{B} \\
\mathrm{C}-\mathrm{D}\end{array}$ \\
\hline $\begin{array}{l}\text { Satisfaction with the process of } \\
\text { public participation }\end{array}$ & respective evaluations & $\mathrm{A}-\mathrm{D}$ \\
\hline Feeling of making a difference & evaluation of effectiveness & $\mathrm{A}-\mathrm{D}$ \\
\hline Becoming a partner & one's feeling of becoming a partner & $\mathrm{C}-\mathrm{D}$ \\
\hline Self-commitment & one's feeling of commitment & $\mathrm{C}-\mathrm{D}$ \\
\hline
\end{tabular}




\section{Analyses}

Analyses were done separately for each dimension of the conceptual framework and for each participation technique. Accordingly, the average values of each indicator were calculated for each stage of the planning process, as well as their total averages. At each stage, the total averages of the two participation techniques were indexed to the maximum score possible at that stage, according to its relevant mix of indicators. The indexed value indicates the achievement level of each technique on each dimension. Index comparisons were then used to test the research hypotheses.

\section{The participants}

Basic comparisons were used to examine differences between the participants of the two techniques. We first looked at the distribution of participants according to the type of participation, and then we compared the respective socioeconomic profiles.

\section{Types of participation}

In $200314 \%$ of the Shapira residents (7997 people) had private access to the web (the respective national average was $24 \%$ ), while free access was available to all at the local community center. The relatively low number of residents with direct access to the web did not affect the process. Apparently, there were 3079 visits to the participation website during the planning period, of which $517(16.8 \%)$ were actual participation visits.

The traditional participation technique included ten meetings and workshops, of which four were junctions, summarizing each of the major planning stages. There were 490 participants who attended these junction meetings. Each group of traditional and web participants included people who participated in the meetings, or repeatedly entered the website without filling out or returning questionnaires, people who filled out questionnaires either at the meetings or on the web, and people who participated in both forms (meetings and web) either with or without submitting questionnaires. Although the meetings and the web questionnaires enabled us to identify those participating in both forms, there was no mechanism to recognize the same participant on the website and at the meetings; the type of participation was identified from the stagewise questionnaires and the total counts at each stage. However, this procedure still enabled us to base the study on comparisons between three groups: (a) those participating only in the traditional technique (TPP); (b) those participating only through the web (WPP); and (c) those participating in both (TWPP). Table 2 presents the distribution of participants in each of the groups, according to their type of participation. Accordingly, the analyses were based only on those who completed questionnaire(s): 108 TPPs, 29 WPPs, and 60 TWPPs. Evidently, only $11.6 \%$ of the total participation-related entrants to the website filled out questionnaires $(29+31$ out of 517$)$. This figure is within the average range of 'click-through rates' found in general e-marketing research $(5 \%-15 \%)$, according to e-consultancy (www.w-consultancy.com/forum).

Of the 1007 total participants (490 meeting attendees and 517 web visitors), 463 were identified as traditional participants (labeled as TPPs), 484 as web participants (WPPs), and 60 were identified as both (TWPPs). Their participation distribution through the four major planning junctions is shown in table 3. Clearly noticed is the relatively small number of meeting attendees at stage C (34 TPPs and 14 TWPPs), which was due to the nature of this particular participation junction. It was not an open, unlimited, type of participation call, but rather an invitation for sixty interested residents to form four intensive working and evaluation groups. Web participation was, however, totally open, as before (with 83 responding participants). 
Table 2. Distribution of participants according to technique and type of participation.

\begin{tabular}{|c|c|c|c|}
\hline $\begin{array}{l}\text { Number of } \\
\text { participants }\end{array}$ & $\begin{array}{l}\text { Source of } \\
\text { information }\end{array}$ & Type of participation & $\begin{array}{l}\text { Participation } \\
\text { technique }\end{array}$ \\
\hline $\begin{array}{l}355 \\
108 \\
463\end{array}$ & $\begin{array}{l}\text { counting } \\
\text { questionnaires }\end{array}$ & $\begin{array}{l}\text { without questionnaires } \\
\text { with questionnaires } \\
\text { total }\end{array}$ & $\begin{array}{l}\text { TPP } \\
\text { (traditional only) }\end{array}$ \\
\hline $\begin{array}{l}455 \\
29 \\
484\end{array}$ & $\begin{array}{l}\text { counting } \\
\text { questionnaires }\end{array}$ & $\begin{array}{l}\text { without questionnaires } \\
\text { with questionnaires } \\
\text { total }\end{array}$ & $\begin{array}{l}\text { WPP } \\
\text { (web only) }\end{array}$ \\
\hline $\begin{array}{l}\text { Part of the } 355 \\
29 \\
\text { Part of the } 455 \\
31 \\
60\end{array}$ & $\begin{array}{l}\text { none }{ }^{\mathrm{a}} \\
\text { questionnaires } \\
\text { none }^{\mathrm{c}} \\
\text { questionnaires }\end{array}$ & $\begin{array}{l}\text { TPP and WPP without questionnaires }{ }^{b} \\
\text { TPP and WPP with questionnaires }{ }^{b} \\
\text { WPP and TPP without questionnaires } \\
\text { WPP and TPP with questionnaires } \\
\text { total with questionnaires }\end{array}$ & $\begin{array}{l}\text { TWPP } \\
\text { (both traditional } \\
\text { and web) }\end{array}$ \\
\hline \multicolumn{4}{|c|}{$\begin{array}{l}{ }^{a} \text { Did not complete a questionnaire, but are still part of the TPP counted participants. } \\
{ }^{b} \text { Residents first participated in the meeting(s) and then joined the web. } \\
{ }^{c} \text { Did not complete a questionnaire, but are still part of the WPP counted participants. } \\
\text { d Residents first entered the web and then joined the meeting(s). } \\
\text { Note. TPP: traditional public participation; WPP: web public participation; TWPP: traditional } \\
\text { and web public participation. }\end{array}$} \\
\hline
\end{tabular}

Table 3. Distribution of participants according to type of participation and planning stage.

\begin{tabular}{lrrl}
\hline Planning stage & \multicolumn{3}{c}{ Type of participation } \\
\cline { 2 - 3 } & TPP & WPP & TWPP \\
\hline A & 267 & 137 & 12 \\
B & 100 & 213 & 21 \\
C & 34 & 83 & 14 \\
D & 62 & 51 & 13 \\
Total & 463 & 484 & 60
\end{tabular}

Note. TPP: traditional public participation; WPP: web public participation; TWPP: traditional and web public participation.

\section{Socioeconomic profiles}

The emerging profiles shown in table 4 are based on self-defined answers and indicate that public participation was generally by the more educated residents, to a slightly greater degree by females, mainly by those in their 30 s and $40 \mathrm{~s}$, basically of whitecollar status, and somewhat equally divided in religiosity. It is common in Israel to divide social groups according to their religious observance. Among the total participants, the religious residents were slightly the majority, while on the national average they constitute $30 \%$ of the population.

As regards the participation technique, there was a clear difference between the WPP and TPP forms, whereas TWPP was somewhere in the middle, with a tendency towards the characteristics of web-only participants. Web participants of both types included a higher percentage of business owners, probably owing to schedule limitations in attending neighborhood meetings. There were, however, more females in WPP, as well as clearly more younger residents, mainly in their 20 s and 30 s $(83.3$ of them were under 40 years versus $52.5 \%$ among TPP participants, and $34.6 \%$ among TWPP participants). WPP participants generally had high-school education, 
Table 4. Distribution (in \%) of selected participants' characteristics according to type of participation.

\begin{tabular}{|c|c|c|c|c|c|}
\hline \multicolumn{2}{|l|}{ Characteristics } & $\begin{array}{l}\text { ТPP } \\
(n=108)\end{array}$ & $\begin{array}{l}\text { TWPP } \\
(n=60)\end{array}$ & $\begin{array}{l}\text { WPP } \\
(n=29)\end{array}$ & $\begin{array}{l}\text { Shapira }{ }^{\mathrm{a}} \\
(n=7997)\end{array}$ \\
\hline $\begin{array}{l}\text { Local affiliation } \\
(p<0.001)\end{array}$ & $\begin{array}{l}\text { resident } \\
\text { business owner } \\
\text { resident and business owner } \\
\text { nonresident }\end{array}$ & $\begin{array}{r}85.1 \\
6.9 \\
2.3 \\
5.7\end{array}$ & $\begin{array}{r}70.0 \\
- \\
23.6 \\
6.4\end{array}$ & $\begin{array}{c}61.5 \\
- \\
23.1 \\
15.4\end{array}$ & $\begin{array}{l}\text { na } \\
\text { na } \\
\text { na } \\
\text { na }\end{array}$ \\
\hline Gender & $\begin{array}{l}\text { female } \\
\text { male }\end{array}$ & $\begin{array}{l}55.1 \\
44.9\end{array}$ & $\begin{array}{l}53.3 \\
46.7\end{array}$ & $\begin{array}{l}66.7 \\
33.3\end{array}$ & \\
\hline Age (years) & $\begin{array}{l}<18 \\
18-28 \\
29-39 \\
40-49 \\
50-59 \\
\geqslant 60\end{array}$ & $\begin{array}{r}2.3 \\
10.2 \\
42.0 \\
25.0 \\
11.4 \\
9.1\end{array}$ & $\begin{array}{r}3.8 \\
7.7 \\
26.9 \\
53.8 \\
3.8 \\
3.8\end{array}$ & $\begin{array}{c}- \\
33.3 \\
50.0 \\
16.7 \\
- \\
-\end{array}$ & $\begin{array}{l}\text { na } \\
25.1 \\
24.9 \\
18.2 \\
18.0 \\
13.5\end{array}$ \\
\hline $\begin{array}{l}\text { Religiosity } \\
(p<0.004)\end{array}$ & $\begin{array}{l}\text { secular } \\
\text { orthodox } \\
\text { extremely orthodox } \\
\text { other }\end{array}$ & $\begin{array}{l}34.1 \\
20.5 \\
33.0 \\
12.5\end{array}$ & $\begin{array}{r}40.0 \\
46.7 \\
3.3 \\
10.0\end{array}$ & $\begin{array}{l}53.3 \\
26.7 \\
- \\
20.0\end{array}$ & $\begin{array}{l}\text { na } \\
\text { na } \\
\text { na } \\
\text { na }\end{array}$ \\
\hline Education & $\begin{array}{r}<12 \text { school years } \\
12 \text { school years } \\
>12 \text { school years }\end{array}$ & $\begin{array}{l}16.3 \\
46.5 \\
37.2\end{array}$ & $\begin{array}{l}13.3 \\
26.7 \\
60.0\end{array}$ & $\begin{array}{l}14.3 \\
64.3 \\
21.4\end{array}$ & $\begin{array}{l}22.9 \\
63.7 \\
13.4\end{array}$ \\
\hline $\begin{array}{l}\text { Occupation } \\
(p<0.024)\end{array}$ & $\begin{array}{l}\text { academic and managerial } \\
\text { clerical and sales } \\
\text { industry and construction } \\
\text { other services } \\
\text { unprofessional and others }\end{array}$ & $\begin{array}{r}33.3 \\
17.3 \\
6.2 \\
17.3 \\
6.2\end{array}$ & $\begin{array}{r}70.0 \\
5.0 \\
5.0 \\
10.0 \\
10.0\end{array}$ & $\begin{array}{c}25.0 \\
50.0 \\
- \\
25.0 \\
-\end{array}$ & $\begin{array}{l}5.0 \\
12.6 \\
20.4 \\
11.8 \\
50.2\end{array}$ \\
\hline
\end{tabular}

${ }^{a}$ Based on 2003 field survey in the neighborhood.

Notes. na-not available; gray shading denotes a significant difference between respective cells; TPP: traditional public participation; WPP: web public participation; TWPP: traditional and web public participation.

and mainly worked in clerical services and sales, whereas a significantly greater number of the TWPP participants had a higher education and held academic and managerial positions. This may explain the slightly higher age of TWPP participants and the fact that very few of the web users were extremely orthodox (none of them in WPP and only $3.3 \%$ in TWPP). One possible explanation is the internal limitation of the extremely orthodox community to the whole issue of the accessing the Internet.

The comparison between the three types of participation profile reveals differences that reflect the expected characteristics of web users in general and of WPP in particular. These differences may reflect the profile of those who are more frequently exposed to information and, at least for TWPP, probably more interested in involvement and their ability to influence their future in the neighborhood. TPP attracts more religious residents, who still do not use the web widely, and/or older people (in their 50s and 60s), who are accustomed to, and believe in, unmediated contacts. These characteristics may explain some of the differences in the contribution of the web to public participation, discussed later on. 


\section{Contribution to public involvement}

The first measured component of the involvement dimension is participation. As defined above, it was measured, objectively, by the number of questionnaires filled out by each participant throughout the two most effective stages, (C) and (D), of the planning process. Accordingly, a low level of involvement indicates those who either attended the meetings or entered the website without filling in any questionnaire. This level is not relevant to TWPP, who, by definition, had to submit at least one questionnaire. A medium level of involvement refers to those who submitted only one questionnaire, while a high level of involvement refers to those who submitted questionnaires for at least two consecutive stages (previous and current).

A comparison of this actual indicator of TPP, WPP, and TWPP participants in expressing their opinions and voting reveals a clear contribution of the web-based technique to the overall involvement dimension. Significantly, in figure 3 , it should be noted that the lowest level of involvement was found among TPP participants $(63.5 \%$ of them did not fill out any questionnaire at stages $\mathrm{C}$ and $\mathrm{D}$, in contrast to only $27.9 \%$ among web participants). The medium level of involvement was higher among TWPP and WPP participants $(51.9 \%$ and $41.4 \%$ of them, respectively). At the high level of involvement $48.1 \%$ of the TWPPs and $30.7 \%$ of the WPPs questionnaires for at least two consecutive stages, while only $4.1 \%$ of the TPPs did the same. These results might indicate that TWPP participants were probably residents who wished to be more affirmatively involved and effective and that the web-based technique increases the number of intervening opportunities available to them. In this respect WPP is more a complementary approach for TPP than a replacement approach.

As to the subjective evaluation of involvement. Table 5 presents the distribution of the subjective $(1-5)$ scalewise evaluations according to planning stage and type of participation. The higher subjective feelings of involvement (ie higher average scores)

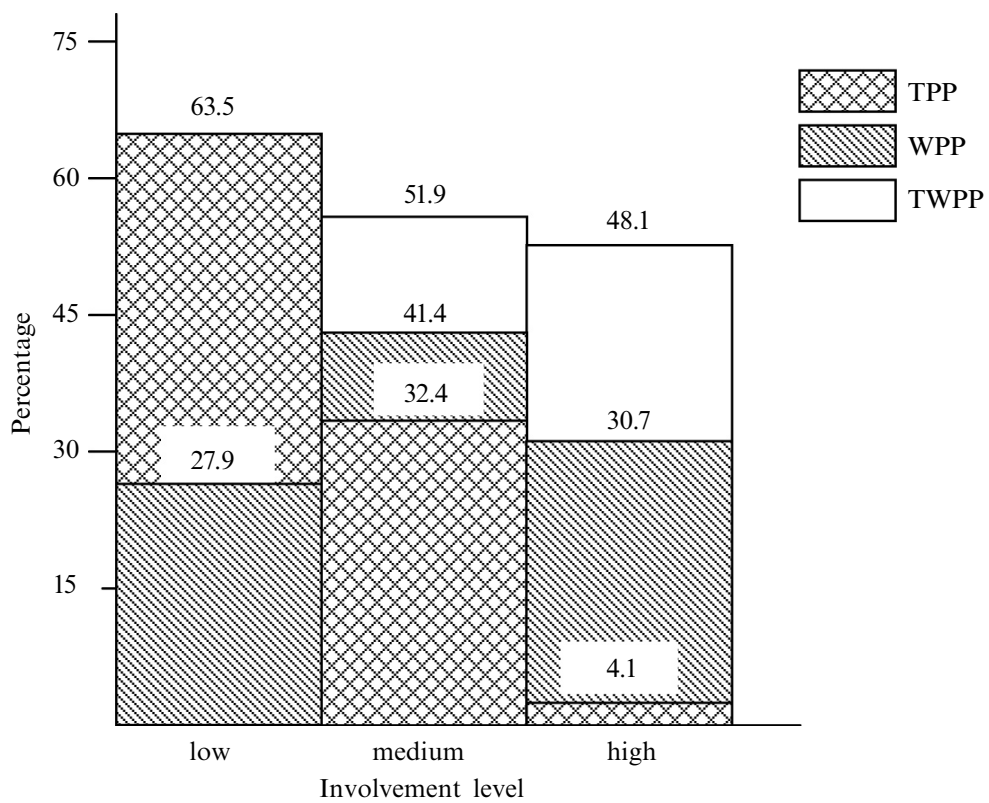

Figure 3. Distribution of involvement level according to type of public participation. Low: did not complete a questionnaire; medium: completed a questionnaire either at the meeting or through the web; high: completed questionnaires at two consecutive stages. TPP, WPP, and TWPP denote public participation in traditional, web-based, and combined methods, respectively. 
Table 5. Subjective evaluations of involvement (averages of 1-5 scale) according to type of participation.

\begin{tabular}{llll}
\hline \multirow{2}{*}{ Planning stage } & \multicolumn{3}{l}{ Average involvement score } \\
\cline { 2 - 4 } & TPP & TWPP & WPP \\
\hline $\begin{array}{l}\text { C Design and evaluation of } \\
\quad \text { alternatives }\end{array}$ & 3.85 & 3.50 & 3.66 \\
$\begin{array}{l}\text { D Formation of policies and } \\
\text { means for implementation }\end{array}$ & 3.25 & 3.62 & 2.00 \\
Total average & 3.55 & 3.56 & 3.00 \\
$\begin{array}{l}\text { Significance } \\
\quad \text { a : TPP-TWPP-WPP }\end{array}$ & & 0.08 & \\
$\quad$ at stage C & & 0.04 & \\
$\quad \begin{array}{l}\text { at stage D } \\
\quad \text { total }\end{array}$ & & 0.02 & \\
a $\chi^{2}$ test.
\end{tabular}

Note. TPP: traditional public participation; WPP: web public participation; TWPP: traditional and web public participation.

that existed among TPP and WPP participants at stage C (which are significant only at the 0.92 level) are smaller in stage D (and significant at the 0.96 level), while the opposite occurs among TWPP participants. The total difference among the participation techniques is, however, significant at the 0.98 level (table 5). The comparison of WPP and TWPP participants' feelings indicates that participation only via the web does not necessarily contribute to the sense of involvement. As a complementary means of participation it does contribute in the later stages.

\section{Contribution to public trust}

If, as hypothesized, WPP is supposed to increase public trust in both the planning process and its outcomes, it should first be indicated by a continuous increase in the number of people entering the planning website. As seen in figure 4, there were, on average, 256 new visits to the website every month. Evidently, the total number of monthly 'first-time' visits increased, although with changing growth rates, as indicated by the monthly statistics and their respective average trend line (figure 4). With a continuously growing number of first-time entries to the site, the growing 'above average' number of first-time visits indicates a growing interest in the plan starting from the second planning stage (B-defining goals and objectives), to the third ( $\mathrm{C}$ design and evaluation of alternatives), followed by a stabilized growth to its final stage (D-formation of policies and implementation means).

Although it might not have been directly related to growing trust, but simply to curiosity, one would not expect the growth of repeated entries, as presented in the monthly data in figure 5, without a gradual build-up of trust in the process. Thus, the accumulated growth of repeated entries, which includes, at every planning stage, part of the first-time entries (as well as other 'established' users), reflects a steady participation, and indicates that trust was being built-up continuously throughout the planning process. This finding is an objective indication that might support the hypothesis that the qualities of web-based participation increase trust.

On the subjective side, table 6 presents the distribution of the participants' evaluation regarding the beneficiaries of the plan. As previously explained, the more the participants believe that the plan contributes to the public, the more they trust it. The results show, without exception, that not only was the main beneficiary seen to be the public, but for both techniques its share was steadily increasing throughout the planning process. 




Figure 4. Distribution of monthly 'first-time' entries to the Shapira neighborhood planning website.

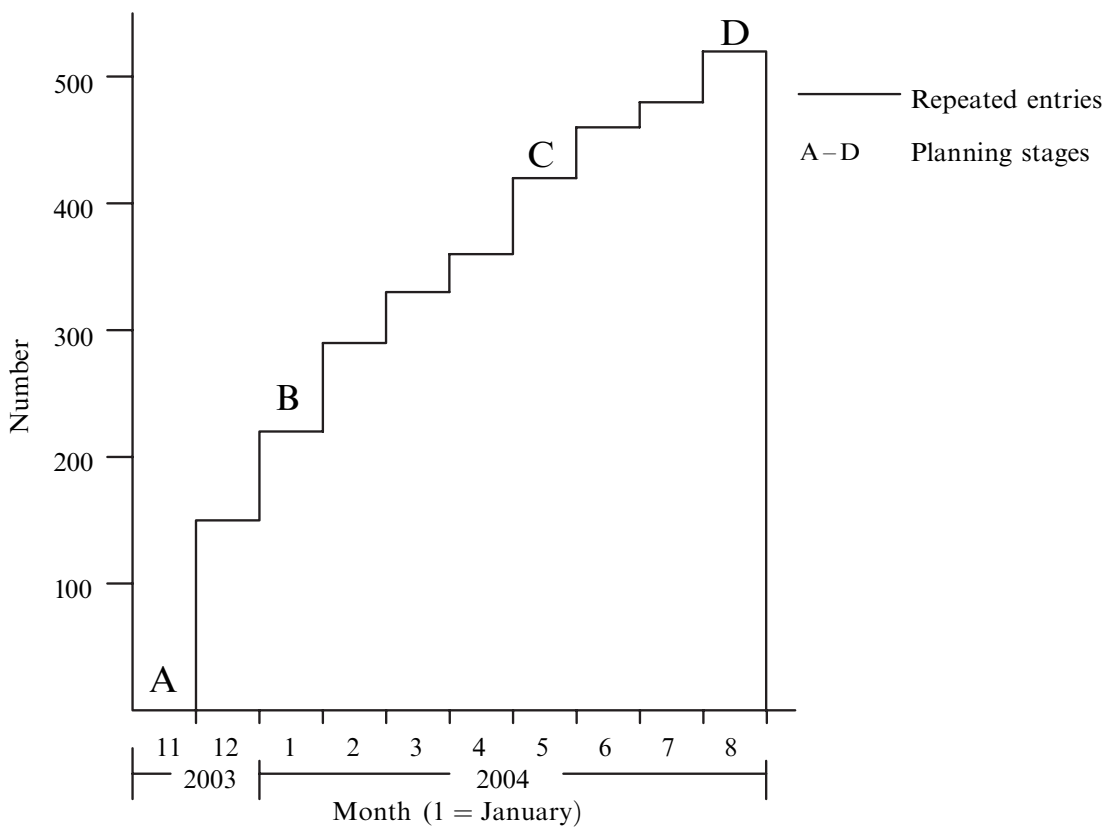

Figure 5. Accumulated distribution of repeated entries to the Shapira neighborhood planning website.

Some decrease is evidenced towards the end of the process, owing to the nature of the last planning stage, in which the policies formed and their extracted means for implementation were of concern to a wide array of target populations and needs.

The public's benefits from the plan are evaluated higher (but only at the $94 \%$ level of significance) by both types of web participants, with noticeably larger percentages among TWPP participants. As trust increased among TPP participants, both the municipality and the planners were regarded as receiving fewer benefits, although those of the municipality were still considered to be relatively high. WPP participants did not consider either the planners or the municipality as beneficiaries, which may 
Table 6. Distribution (in \%) of evaluated beneficiaries according to planning stage and type of participation.

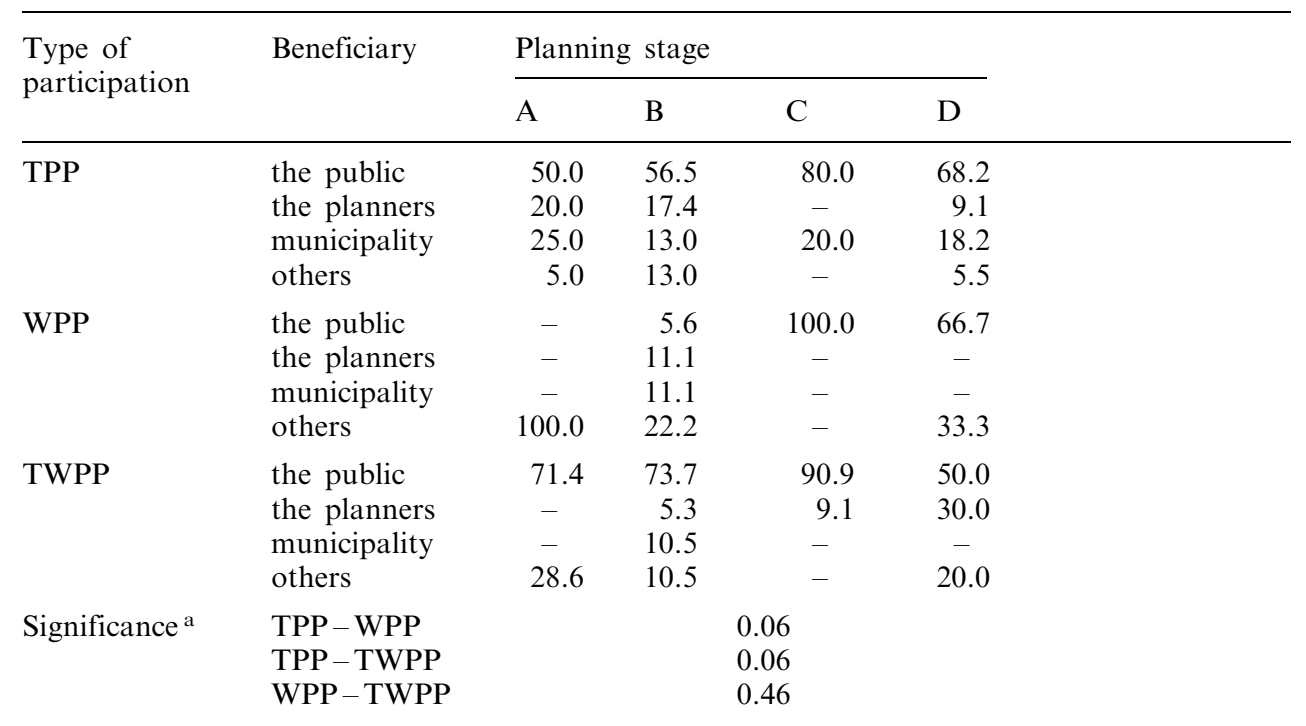

${ }^{\mathrm{a}} \chi^{2}$ test.

Note. TPP: traditional public participation; WPP: web public participation; TWPP: traditional and web public participation.

be the result of the somewhat 'sterile' information provided on the web, without participants actually hearing any of the planners or the representatives of the municipality. TWPP participants, who used the web-offered opportunities and also had unmediated contacts with the planners and the municipality representatives, believed they saw, simultaneously, increasing benefits to the planners but only very small overall benefits to the municipality. These results support the hypothesis that people who become more involved and affective in the planning process will not only trust it more, but will trust the planners as well.

\section{Contribution to empowerment}

A summary of the distribution of all empowerment indicators according to planning stage and type of participation is presented in table 7. Since some indicators were relevant only at certain stages (see table 1), some cells in table 7 are empty. Overall indexed scores are shown at the bottom of the table. Calculated separately for each of the planning stages according to its relevant indicators, the scores reflect the total contribution to the empowerment of the public of each type of participation, at each stage (in percentages out of the total possible score of each column). Evidently, there is already a slight contribution of web-based participation at the first stage of planning, where TWPP participants are satisfied with the process, feel they have the highest access to information, and can make some difference as well. A rapid increase is then noticed in all the other indicators from the second stage onwards. At first, only WPP participants seemed to be significantly empowered, as reflected mainly by their ability to influence the formulation of goals and their general satisfaction with the process. At later stages (C and D), web-based participation seems to have had a greater affect on the TWPP participants, as they showed higher, and often significantly different, scores in all the other empowerment indicators. 
Table 7. Empowerment indicators (average evaluation of $1-5$ scores) by type of public participation.

\begin{tabular}{|c|c|c|c|c|c|c|c|c|c|c|c|c|c|c|c|}
\hline \multirow[t]{3}{*}{ Indicator } & \multicolumn{15}{|c|}{ Planning stage } \\
\hline & \multicolumn{5}{|l|}{$\mathrm{TPP}$} & \multicolumn{5}{|l|}{ WPP } & \multicolumn{5}{|l|}{ TWPP } \\
\hline & A & B & $\mathrm{C}$ & $\mathrm{D}$ & total & A & B & $\mathrm{C}$ & $\mathrm{D}$ & total & A & B & $\mathrm{C}$ & $\mathrm{F}$ & total \\
\hline Access to information & $\begin{array}{l}2.37 \\
(0.20)\end{array}$ & $\begin{array}{l}3.38 \\
(0.002)\end{array}$ & $\begin{array}{l}4.14 \\
(0.64)\end{array}$ & $\begin{array}{l}3.21 \\
(0.14)\end{array}$ & $\begin{array}{l}3.16 \\
(0.05)\end{array}$ & $\begin{array}{l}1.00 \\
(0.20)\end{array}$ & $\begin{array}{l}3.00 \\
(0.002)\end{array}$ & $\begin{array}{l}4.66 \\
(0.64)\end{array}$ & $\begin{array}{l}3.00 \\
(0.14)\end{array}$ & $\begin{array}{l}2.93 \\
(0.05)\end{array}$ & $\begin{array}{l}3.60 \\
(0.20)\end{array}$ & $\begin{array}{l}3.37 \\
(0.002)\end{array}$ & $\begin{array}{l}4.14 \\
(0.64)\end{array}$ & \begin{tabular}{|l|}
3.71 \\
$(0.14)$
\end{tabular} & $\begin{array}{l}3.70 \\
(0.05)\end{array}$ \\
\hline $\begin{array}{l}\text { Affecting the formulation } \\
\text { of goals }\end{array}$ & - & $\begin{array}{l}3.64 \\
(0.009)\end{array}$ & - & - & $\begin{array}{l}3.64 \\
(0.009)\end{array}$ & - & $\begin{array}{c}4.50 \\
(0.009)\end{array}$ & - & - & $\begin{array}{c}4.50 \\
(0.009)\end{array}$ & - & $\begin{array}{l}3.57 \\
(0.009)\end{array}$ & - & - & $\begin{array}{c}3.57 \\
(0.009)\end{array}$ \\
\hline $\begin{array}{l}\text { Affecting the selection of } \\
\text { alternatives }\end{array}$ & - & - & $\begin{array}{c}3.57 \\
(0.58)\end{array}$ & - & $\begin{array}{c}3.57 \\
(0.53)\end{array}$ & - & - & $\begin{array}{c}4.00 \\
(0.58)\end{array}$ & - & $\begin{array}{c}4.00 \\
(0.53)\end{array}$ & - & - & $\begin{array}{c}4.14 \\
(0.58)\end{array}$ & - & $\begin{array}{c}4.14 \\
(0.53)\end{array}$ \\
\hline $\begin{array}{l}\text { Affecting conflict } \\
\text { resolution }\end{array}$ & - & - & $\begin{array}{c}3.80 \\
(0.25)\end{array}$ & $\begin{array}{c}3.26 \\
(0.17)\end{array}$ & $\begin{array}{c}2.40 \\
(0.03)\end{array}$ & - & - & $\begin{array}{c}4.00 \\
(0.25)\end{array}$ & $\begin{array}{c}2.00 \\
(0.17)\end{array}$ & $\begin{array}{c}1.00 \\
(0.03)\end{array}$ & - & - & $\begin{array}{c}3.83 \\
(0.25)\end{array}$ & $\begin{array}{c}3.14 \\
(0.17)\end{array}$ & $\begin{array}{c}3.80 \\
(0.03)\end{array}$ \\
\hline $\begin{array}{l}\text { Satisfaction with the } \\
\text { process }\end{array}$ & $\begin{array}{c}2.56 \\
(0.35)\end{array}$ & $\begin{array}{l}4.00 \\
(0.10)\end{array}$ & $\begin{array}{c}4.20 \\
(0.75)\end{array}$ & $\begin{array}{c}4.43 \\
(0.16)\end{array}$ & $\begin{array}{c}3.42 \\
(0.03)\end{array}$ & - & $\begin{array}{c}4.42 \\
(0.10)\end{array}$ & $\begin{array}{l}4.66 \\
(0.75)\end{array}$ & $\begin{array}{c}3.00 \\
(0.16)\end{array}$ & $\begin{array}{l}4.15 \\
(0.03)\end{array}$ & $\begin{array}{l}2.80 \\
(0.35)\end{array}$ & $\begin{array}{c}4.00 \\
(0.10)\end{array}$ & $\begin{array}{c}4.57 \\
(0.75)\end{array}$ & $\begin{array}{c}3.42 \\
(0.16)\end{array}$ & $\begin{array}{c}3.76 \\
(0.03)\end{array}$ \\
\hline $\begin{array}{l}\text { Feeling of making a } \\
\text { difference }\end{array}$ & $\begin{array}{c}2.56 \\
(0.50)\end{array}$ & $\begin{array}{l}3.75 \\
(0.03)\end{array}$ & $\begin{array}{c}4.28 \\
(0.14)\end{array}$ & $\begin{array}{l}3.08 \\
(0.43)\end{array}$ & $\begin{array}{l}3.22 \\
(0.52)\end{array}$ & - & $\begin{array}{c}2.85 \\
(0.03)\end{array}$ & $\begin{array}{l}3.66 \\
(0.14)\end{array}$ & $\begin{array}{c}2.33 \\
(0.43)\end{array}$ & $\begin{array}{c}2.92 \\
(0.52)\end{array}$ & $\begin{array}{l}3.40 \\
(0.50)\end{array}$ & $\begin{array}{c}3.71 \\
(0.03)\end{array}$ & $\begin{array}{c}4.00 \\
(0.14)\end{array}$ & $\begin{array}{c}3.85 \\
(0.43)\end{array}$ & $\begin{array}{c}3.76 \\
(0.52)\end{array}$ \\
\hline $\begin{array}{l}\text { Feeling of becoming } \\
\text { a partner }\end{array}$ & - & - & $\begin{array}{c}4.14 \\
(0.01)\end{array}$ & $\begin{array}{c}3.21 \\
(0.02)\end{array}$ & $\begin{array}{c}3.43 \\
(0.03)\end{array}$ & - & - & $\begin{array}{l}3.66 \\
(0.01)\end{array}$ & $\begin{array}{c}1.00 \\
(0.02)\end{array}$ & $\begin{array}{c}2.33 \\
(0.03)\end{array}$ & - & - & $\begin{array}{c}3.66 \\
(0.01)\end{array}$ & $\begin{array}{c}4.14 \\
(0.02)\end{array}$ & $\begin{array}{c}3.9 \\
(0.03)\end{array}$ \\
\hline $\begin{array}{l}\text { Feeling of self- } \\
\text { commitment }\end{array}$ & - & - & $\begin{array}{c}4.14 \\
(0.70)\end{array}$ & $\begin{array}{c}3.77 \\
(0.01)\end{array}$ & $\begin{array}{l}3.86 \\
(0.01)\end{array}$ & - & - & $\begin{array}{c}4.33 \\
(0.70)\end{array}$ & $\begin{array}{c}2.00 \\
(0.01)\end{array}$ & $\begin{array}{l}3.16 \\
(0.01)\end{array}$ & - & - & $\begin{array}{c}4.38 \\
(0.70)\end{array}$ & $\begin{array}{c}3.85 \\
(0.01)\end{array}$ & $\begin{array}{c}4.07 \\
(0.01)\end{array}$ \\
\hline $\begin{array}{l}\text { Overall indexed score }{ }^{a} \\
\quad \text { (in } \%)\end{array}$ & 49.93 & 73.88 & 80.77 & 69.86 & - & 20.00 & 73.85 & 82.77 & 44.43 & - & 65.33 & 73.25 & 82.05 & 73.70 & - \\
\hline
\end{tabular}
(in $\%$

Significant difference $[p(T \leqslant t)]$ between respective cells. Higher values in web-involved participation.

a The scores reflect the total contribution to the empowerment out of the total possible score of each column.

Note. TPP: traditional public participation; WPP: web public participation; TWPP: traditional and web public participation. 
A stagewise examination of the changes in the subjective evaluations of the empowerment indicators shows, with only one exception (a continuous increase in satisfaction among TPP participants), a gradual increase up to stage $\mathrm{C}$, and then some decrease in the contribution to empowerment at stage $\mathrm{D}$. The latter is probably a more demanding task for the common public and requires more professional skills and experience.

When we look at the vertical order of the indicators in table 7, which reflects the development continuum of empowerment throughout the planning period (previously presented in table 1), we can see an increasing, significant, contribution of the webbased technique to the empowerment of the TWPP participants. At stage D, TWPP participants already had the strongest feelings of 'becoming a partner' and, immediately after, of 'self-commitment'. Clearly noticeable, however, was the relatively small contribution, at this stage, of the web-based technique to WPP participants who had no unmediated 'human contacts' throughout the planning process. At this stage TPP participants were empowered more than the WPP participants. This finding therefore reflects, as before, the contribution of the web-based participation to empowerment, as a complementary means, but not as a replacement for TPP. This contribution is probably due to the additional range of intervention opportunities that WPP offers.

\section{Overall evaluation and discussion}

This study tackles the question of whether the potential advantages of WPP are only complementary to the benefits of TPP, or if they are sufficiently empowering to replace them. The answer is partially apparent in figure 6, which summarizes, with indexed scores, the stagewise comparisons of all the subjective measures of the benefits gained by the three types of participation.

Involvement, in terms of the personal relevance of the participation technique, was higher with TPP only at stage C. A slight decrease in the contribution of TPP to involvement at stage $\mathrm{D}$ and a slight increase in the contribution of the web-based technique at stage D increased the feelings of involvement only among TWPP participants. Web-based participation did not increase involvement among WPP participants. Despite the increase in popularity and usage, web-based participation is a relatively new tool, not only for the planners, but certainly also for the public, which still has difficulty in accepting it as a better tool. This observation is strengthened by the results of the respective indicator that measured the level of participation, which indicated that WPP contributed mainly as an additional opportunity for involvement and, in this respect, was complementary to TPP.

However, we did not envisage one limitation of the study. TWPP participants were clearly the most committed to engagement in the process, if only in terms of the time they invested in it. However, a comparison between them and the other two groups should have focused on those in each of them with the same level of commitment. Obviously, someone who participated in all four stages-whether through TPP or WPP - was more comparable to a TWPP participant than someone who just attended one meeting or made a single visit to the website. Unfortunately, such a comparison was impossible, as we had no mechanism to follow the history of each participant throughout all the stages. We could only know about participation in the 'previous stage'. Future research should pay attention to this point.

Turning to trust, we noted a slight difference from the sense of involvement: webonly participants gained more trust in the plan than TPP participants only at stage C. However, TWPP participants developed a greater trust in the plan than their TPP counterparts throughout most of the planning process. This evidence, that participants of both techniques developed a higher level of trust than that developed by those 


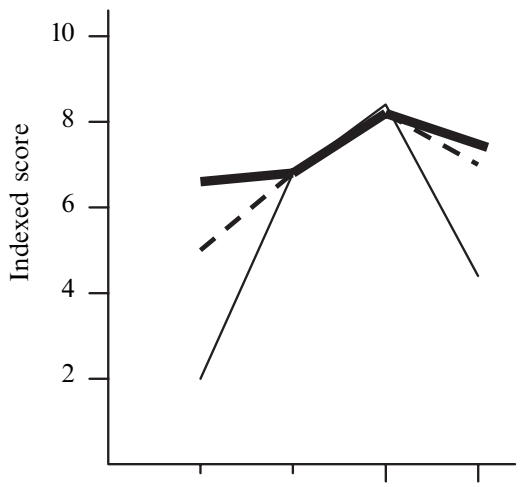

(a)

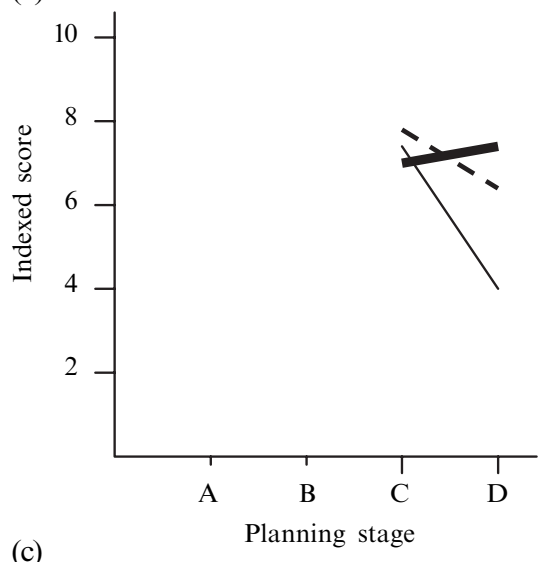

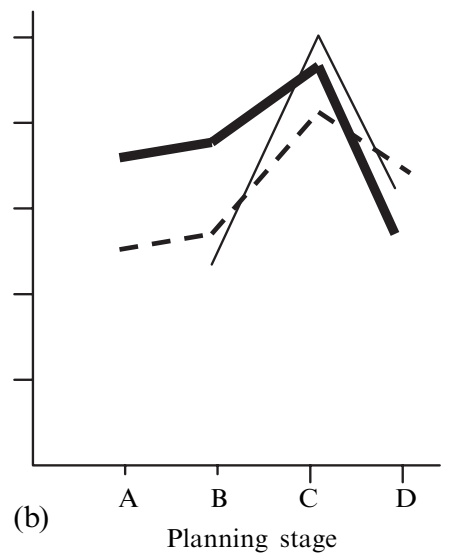

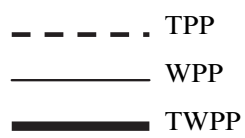

Figure 6. Subjective measures of benefits gained (by indexed scores, computed in the same way as in table 7), according to type of participation. TPP, WPP, and TWPP denote public participation via traditional, web, and combined methods, respectively. (a) Empowerment; (b) trust; (c) involvement.

participating only in TPP, may explain both the high level of trust gained, already at the beginning of the process, and its higher continuous contribution.

As regards empowerment, the overall indexed scores show a significant contribution of the web-based technique to TWPP participants. Except for stage C, there was only a small effect on web-only participants. TPP empowered the public, in most stages, significantly more than did the web-based technique with respect to the webonly participants. This finding might be the result of the proven need for direct, unmediated, connection between all the stakeholders, the municipality, and the planners throughout the planning process (see, eg, Berry, 2004). The literature claims that some communication is needed, even between web-only participants, in order to generate benefits from public participation. A web-based chatting forum might be one of the possible ways to achieve this end. Stronger effects on the process and its products can best be achieved, it seems, only when one can actually be seen and heard (Berry, 2004). This argument explains the higher contribution of the web-based technique to TWPP participants - who had direct contacts with all the stakeholders, but who also used the advantages and the opportunities offered by WPP.

Beyond the comparisons within each of the benefits separately, figure 6 reveals a general, intriguing, drop in trust, empowerment, and involvement in stage D. This might be a result of the participation activities required by the public at this point. 
If maximum public influence is perceived to be through voting, then figure 2 could indicate a drop in this factor at the last planning stage. Starting with 'proposing' and 'discussing' at the beginning of the planning process, the participants were asked to debate and to vote at its second stage. Later, they were asked to evaluate and to choose by voting a selected alternative. These votes ensured their subjective feelings of being part of the evolving plan. However, at the last stage, they only proposed and discussed policy and projects, without any act which could subjectively ensure their ongoing effect on the final product. Furthermore, they could not see, at that time, if their proposed policies and projects were either to be included in the final plan, or to be implemented.

To the best of our knowledge, there are no empirical studies comparing the benefits of one participation technique over the other, unless it is related to the potential benefits of PPGIS. None of the studies we have seen examined empirically the contribution to empowerment, trust, and involvement. Current studies claim, in general, that Internet-based technologies have the potential to widen participation, at least in the UK planning system (eg Kingston et al, 2000). Another recent study claims that the "medium of the web enables us to harness collective intellect among a population in ways face-to-face planning meeting cannot" (Brabham, 2009, page 1). It argues further that web participation would empower citizens to participate. It would give voice not only to those typically excluded from the participation process altogether, but also to those who are typically involved, but are drowned out by polar arguments. Moreover, it argues that web participation might increase involvement, because citizens would have the opportunity to participate in ways that fit their interest in the project. These arguments, however, are not supported empirically, and the results summarized above are probably among the first to emerge from TPP - WPP comparisons.

\section{Conclusions}

The results of the present study show that web-based participants not only differ from TPP participants, but also differ from each other. The more educated, holding academic and managerial positions, in their 30 s to 40 s, are those who use the web as an additional opportunity for active and affective participation. Younger people, residents, and local business owners in their 20 s and 30 s, mainly with only high-school education, are those who participate only through the web, with a lesser drive and ability to be active and effective. The older and more religious residents, who are accustomed to, and believe in, unmediated contacts, are, in general, those who participate only in the traditional meetings.

We may conclude further that the qualities of web-based participation do not, on their own, increase involvement and participation among WPP participants, but only among those who participate both in the traditional meetings and via the website. The same conclusion also applies to the effects of web-based technique on empowerment. TPP can help to empower the public more than it empowers those who participate only through the web. However, it empowers those who participate both in the traditional meetings and through the website significantly more. The same conclusion is drawn with regard to the effect of web participation on trust.

In sum, the three hypotheses are supported only with regard to TWPP participants. It thus shows that WPP is an effective and affective complementary means for public participation, but it cannot yet replace the traditional unmediated techniques.

Acknowledgements. We are grateful to three anonymous reviewers for the helpful comments they generously provided on an earlier draft. 


\section{References}

Barki H, Hartwick J, 1989, "Rethinking the concept of user involvement" Management Information Systems Quarterly $1353-63$

Barki H, Hartwick J, 1994, "Rethinking the concept of user involvement, and user attitude" Management Information Systems Quarterly 1824 - 59

Beierle C Y, Kosinsky M D, 2000, "Values, conflict, and trust in participatory environmental planning" Journal of Policy Analysis and Management $19587-602$

Berry J, 2004, "2D interface to a 3D environment, a proof-of-concept: coupling two software applications for a web-based public participation GIS", MSc thesis, Department of Geomatic Engineering, University College London

Brabham D C, 2009, "Crowdsourcing the citizen participation process for public planning projects" Planning Theory forthcoming, http://ssrn.com/abstract $=1123325$

Brandt M, 2002, "A model for evaluating public participation GIS", in Community Participation and Geographic Information systems Eds W Craig, T Harris, D Weiner (Taylor and Francis, London) pp $346-365$

Brody S D, Godschalk D R, Burby R J, 2003, "Mandating citizen participation in plan making: six strategies planning choices" Journal of the American Planning Association 46245 - 264

Burby R J, 2003, "Making plans that matter: citizens involvement and government action" Journal of the American Planning Association 69 17-33

Carver S, 2001, "Public participation using web-based GIS" Environment and Planning B: Planning and Design 28 803-804

Chamberline J, 1997, “A working definition of empowerment” Psychiatric Rehabilitation Journal $204-43$

Churchman A, Sadan E, 2003 Participation: Your Way to Make a Difference (Hakibbutz Hameuchad, Tel Aviv), in Hebrew

Craig W, Harris T, Weiner D (Eds), 2002 Community Participation and Geographic Information Systems (Taylor and Francis, London)

Dunn E C, 2007, "Participatory GIS-a people's GIS?" Progress in Human Geography 31 616-637

Elwood A S, 2001, "GIS use in community planning: a multidimensional analysis of empowerment" Environment and Planning A $34905-922$

Forester J, 1998, "Creating public value in planning and urban design: the three abiding problems of negotiation, participation and deliberation" Urban Design International 3 5-12

Glaeser L E, Laibson I D, Scheinkman A J, Soutte L C, 2000, "Measuring trust" The Quarterly Journal of Economics 115811 - 846

Halvorsen K E, 2003, "Assessing the effects of public participation" Public Administration Review $63535-543$

Hamilton A, Zhang X, Fernando T, Watson K, 2001, "Learning through visual systems to enhance the urban planning process" Environment and Planning B: Planning and Design 28 833-845

Han S S, Peng Z, 2003, "Public participation GIS (PPGIS) for town council management in Singapore" Environment and Planning B: Planning and Design 30 89-111

Irvin R A, Stansbury J, 2004, "Citizen participation in decision making: is it worth the effort?" Public Administration Review $6455-65$

Jeffries A, 1996, "Modeling community work: analytic framework for practice", in Community Practice: Conceptual Models Ed. M Weil (Haworth Press, New York) pp $101-125$

King S C, Feltey M K, Susel O B, 1998, "The question of participation: towards authentic public participation in public administration" Public Administration Review 58317 - 327

Kingston R, Carver S, Evans A, Turton I, 2000, "Web-based public participation geographical information systems: an aid to local environmental decision-making" Computers, Environment and Urban Systems 24109 - 125

Kingston R, Carver S, Evans A, Turton I, 2001, "Public participation, GIS and cyberdemocracy: evaluating on-line spatial decision support systems" Environment and Planning B: Planning and Design $28907-921$

Lane B M, 2005, "Public participation in planning: an intellectual history" Australian Geographer $36283-299$

Peng Z-R, 2001, "Internet GIS for public participation" Environment and Planning B: Planning and Design $28889-905$

Rappaport J, 1984, "Studies in empowerment: introduction to the issue" Prevention in Human Services 3 1-7

Rocha M E, 1997, "A ladder of empowerment” Journal of Planning and Research 1731 -44 
Sarjakoski T, 1998, "Networked GIS for public participation and GIS on utilizing image data" Computer Environment and Urban Systems 22381 - 392

Sarno D, 2005 Workshop on Public Participation in the ILC (The Perspectives Group, Alexandria, VA), http://www.linearcollider.org/pdf/snowmassfinal.pdf

Schroeder P C, Boudreau P R, Boyce M A, Brehme C W E, Evans A J, Rahmani A, 2001, "The Gulf of Maine Environmental Information Exchange: participation, observation, conservation" Environment and Planning B: Planning and Design 28 865-887

Sieber R, 2006, "Public participation geographic information systems: a literature review and framework" Annals of the American Association of Geography 96491 - 507

Stern E, 2002, "Planning hierarchy and public participation in Israel" Perspective $1438-42$ (in Hebrew)

Stern E, Amir I, 2006, "Benefits of public participation as evaluated by the participating citizens", paper presented at the Annual Conference of Israel Planning Association, Hertzelia (in Hebrew), available from the authors

Talmor K, 2006, "Evaluating a web-based public participation system in the planning process - a case study", MSc thesis, Technion-Israeli Institute of Technology, Haifa (in Hebrew)

Trevor H, 1998, "Empowerment marginalization and 'community-integrated' GIS" Cartography and Geographic Information Systems $2567-76$

Webler T, Tuker S, Kruege R, 2004, "What is a good public participation process? Five perspectives from the public" Environment Management $27435-450$

Wondolleck J M, Yaffee S L, 2000 Making Collaboration Work: Lessons from Innovation in Natural Resource Management (Island Press, Washington, DC)

Zimmerman M, 1990, "Taking aim on empowerment research: on the distinction between individual and psychological conceptions" American Journal of Community Psychology 18 169 - 177

Zimmerman M, Rappaport J, 1988, "Citizen participation, perceived control and psychological empowerment" American Journal of Community Psychology 16725 - 750 
Conditions of use. This article may be downloaded from the E\&P website for personal research by members of subscribing organisations. This PDF may not be placed on any website (or other online distribution system) without permission of the publisher. 